\title{
Determinants of Bank Profitability of Indonesian Banks Based on Core Capital Size in Category 3 And 4
}

\author{
Karen Santoso, Weindytha Patrizia Wibowo, \\ Sammy Kristamuljana, Rathria Arrina Rachman*) \\ Sekolah Bisnis dan Ekonomi - Universitas Prasetiya Mulya \\ BSD City Kavling Edutown I.1 , Jl. BSD Raya Utama, BSD City, Tangerang 15339
}

Keywords:

Banking Sector, Core Capital, Bank Profitability

Kata Kunci:

Sektor Perbankan, Modal Inti, Profitabilitas Bank

*Corresponding Author: rathria.rachman@pmbs.ac.id

\begin{abstract}
:
Indonesian banks are categorized into four classes based on core capital size that determines the scope of banks' business activities. This research aimed to identify the determinants of profitability of banks with the core capital size of IDR 5-30 trillion (called "Buku 3" category) and banks with the core capital size of more than IDR 30 trillion (called "Buku 4" category). The data sample was 27 conventional commercial banks listed on the Indonesia Stock Exchange (BEI) from 2009 to 2018. These banks are divided into three different sample classes namely Buku 3 only, Buku 4 only, and Buku 3 and Buku 4 categories. By applying a panel regression model, the results showed that net interest margin (NIM) positively affected profitability of the banks in Buku 3, banks in Buku 4, as well as banks in Buku 3 and Buku 4 category. Moreover, operating expense to operating income ratio (BOPO) and non-performing loans (NPL) negatively affected profitability of those banks in the three sample classes. However, loan to deposit ratio $(L D R)$ and capital adequacy ratio $(C A R)$ have negative relationships with profitability for banks in the Buku 4 category only. Accordingly, this study finds that banks in different sizes of core capital categories have different factors affecting profitability in the Indonesian banking sector.
\end{abstract}

\section{Abstrak:}

Bank-bank di Indonesia dikelompokan ke dalam empat kelas berdasarkan besarnya modal inti yang menentukan ruang lingkup kegiatan bisnis bank. Penelitian ini bertujuan untuk mengidentifikasi faktor-faktor penentu profitabilitas bank dengan modal inti antara Rp. 5-30 triliun (disebut dengan kategori "Buku 3") dan bank dengan modal inti lebih dari Rp. 30 triliun (disebut dengan kategori "Buku 4"). Sampel data adalah 27 bank umum konvensional yang terdaftar di Bursa Efek Indonesia (BEI) dari tahun 2009 hingga 2018. Bank-bank `ini dibagi menjadi tiga kelas sampel yang berbeda yaitu Buku 3 saja, Buku 4 saja, serta Buku 3 dan Buku 4. Dengan menggunakan model regresi data panel, hasil penelitian ini menunjukkan bahwa rasio pendapatan bunga bersih (NIM) berpengaruh positif terhadap profitabilitas bank di Buku 3, bank di Buku 4, serta bank di Buku 3 dan Buku 4. Selain itu, rasio biaya operasional terhadap pendapatan operasional (BOPO) dan kredit bermasalah (NPL) berpengaruh negatif terhadap profitabilitas bank-bank dalam tiga kelas sampel tersebut. Namun, rasio pinjaman terhadap deposito (LDR) dan rasio kecukupan modal (CAR) memiliki hubungan negatif dengan profitabilitas bank dalam kategori Buku 4 saja. Dengan demikian, penelitian ini menunjukan bahwa bank dengan kelompok modal inti yang berbeda memiliki faktor penentu yang berbeda yang mempengaruhi profitabilitas di sektor perbankan Indonesia. 
Studi Akuntansi \& Keuangan Indonesia

\section{Introduction}

To enhance the resilience and competitiveness of the Indonesian banking system, the central Bank of Indonesia (Bank Indonesia) formally issued a regulation in December 2012 governing banking activities and office networks. It was based on bank core capital stated in Bank Indonesia Regulation No.14/26/2012, which was updated by the Financial Services Authority (Otoritas Jasa Keuangan/OJK) Regulation No. 6/POJK.03/2016. According to these regulations, banks in Indonesia are grouped into four classes called "Buku" (Commercial Banks Business Activities) based on the size of their core capital. The underlying reason for this policy is the importance of core capital for banks' level of security and strength in dealing with operational risk. There are 4 categories for Indonesian banks, namely Buku 1, Buku 2, Buku 3 and Buku 4. Banks in Buku 1 have the lowest core capital ranging from $\mathrm{Rp} 100$ billion to $\mathrm{Rp} 1$ trillion so that they can only run the basic banking business activities. On the other hand, banks in Buku 4 have the highest core of capital above Rp 30 trillion. As a consequence, these banks are allowed to undertake the most complex business activities among others.

In line with data from Financial Services Authority of Indonesia (Otoritas Jasa Keuangan, 2018), 53 per cent of the total bank assets in Indonesia come from banks in Buku 4 and 35 per cent come from banks in Buku 3 category (Figure 1). In other words, almost 90 per cent of total assets in the Indonesian banking sector belong to the banks in these two classes. These banks have a systemic impact on the overall economy by contributing 80 percent of all Indonesian banking activities. Consequently, it is of paramount importance for the government to closely supervise the financial performance of banks in Buku 3 and Buku 4 to ensure the fluency of the overall economic activities.

\begin{tabular}{lr}
\multicolumn{2}{c}{ ASSETS } \\
\hline BUKU 1 & 71.280 \\
BUKU 2 & 823.832 \\
BUKU 3 & 2741.984 \\
BUKU 4 & 4114.559 \\
TOTAL & $\mathbf{7 7 5 1 . 6 5 5}$
\end{tabular}

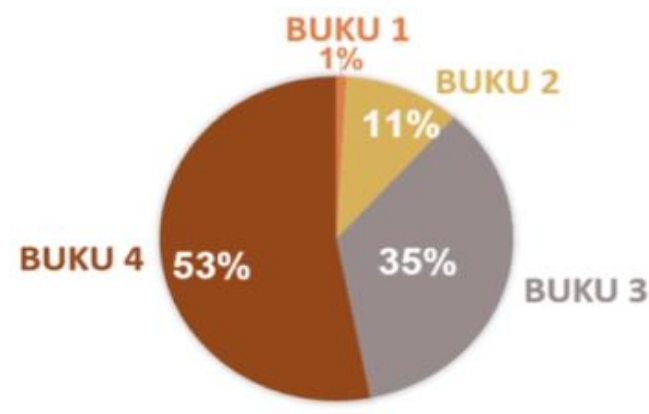




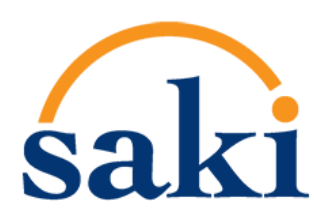

Studi Akuntansi \& Keuangan Indonesia

Figure 1. Asset Size (in Trillion IDR) and Proportion of Asset (percentage) of Indonesian Banks Based on Core Capital Size ("Buku") in December 2018

(Source: Otoritas Jasa Keuangan, 2018)

According to Harahap (2002) and Christiano (2014), the most appropriate indicator to measure performance of a bank is profitability. It reflects the ability of the banks to generate profits. There are various financial ratios to measure profitability; however, return on assets (ROA) can be used to measure bank profitability well (Sutrisno, 2012). The graph in Figure 2 shows the ROA ratio of Indonesian banks from 2015 to 2018. As can be seen, banks in Buku 4 have the highest profitability that is above banks in Buku 3 as well as the average ROA of all commercial banks in Indonesia over the period.

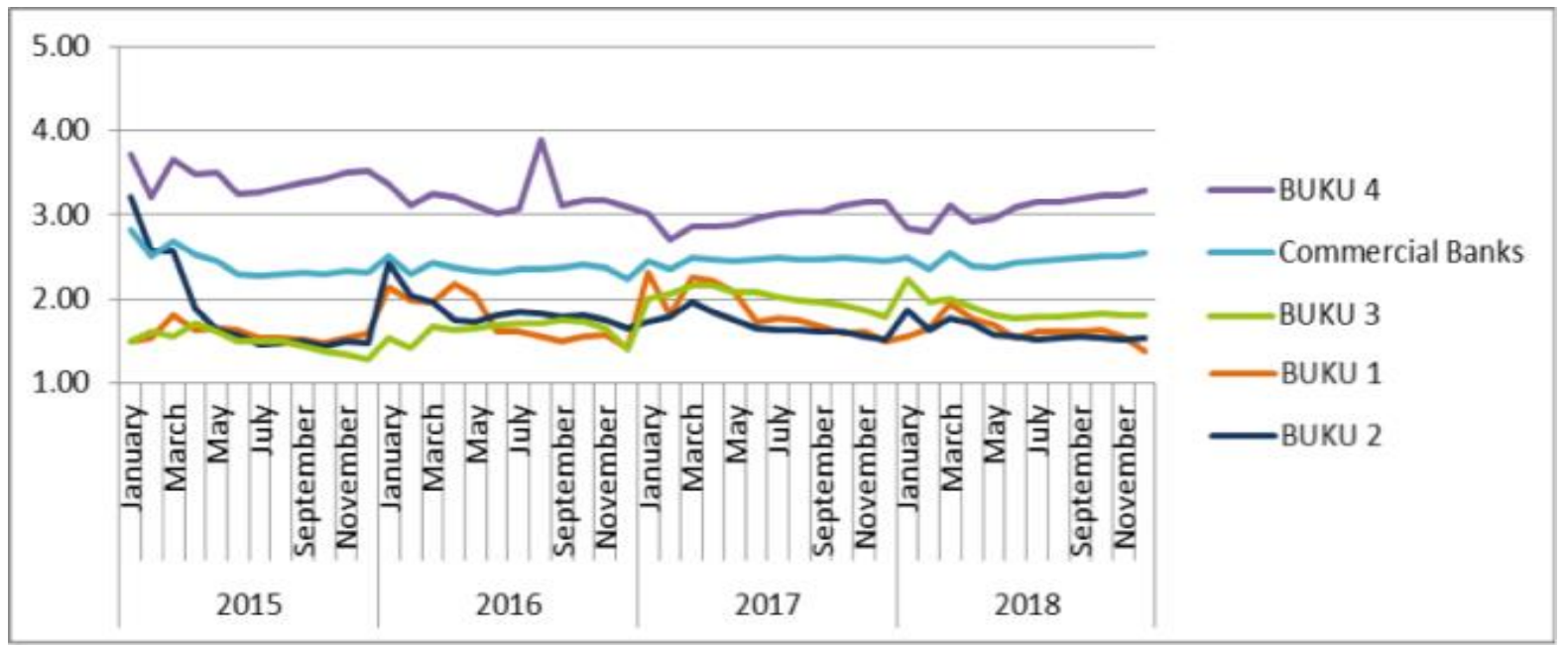

Figure 2. Trends of ROA of Banks in Indonesia

(Source: Otoritas Jasa Keuangan, 2018)

There are numerous previous empirical studies that scrutinized factors contributing to banks' financial performance. However, studies on banks' profitability determinants based on core capitalbased classes were considered very limited. This research categorized banks based on capital-based classes, namely Buku 3 category, Buku 4 category and the combination of Buku 3 and Buku 4 category. Furthermore, this study strives to scrutinize factors that contribute to the bank's profitability from bank-level data of the Indonesian banking sector. By identifying bank-specific factors, banks are able to take action in regards with effort to promote their profitability level. 
Studi Akuntansi \& Keuangan Indonesia

\section{Literature Review and Hypotheses Development}

\section{Literature Review}

According to the Law of the Republic of Indonesia No. 10 Year 1998 dated 10 November 1998, about the Law of Banking, banks are defined as business institutions that collect funds from the public in the form of deposits and allocate them to the community in the form of loans and or other forms to promote the lives of the society. According to Bank Indonesia Regulation No.14/26/2012, banks in Indonesia are divided into 4 categories called "Buku" based on the size of banks' core capital (Table $1)$.

Table 1. Bank Classification in Indonesia Based on Core Capital

\begin{tabular}{|c|l|l|}
\hline Category & \multicolumn{1}{|c|}{ Size of Core Capital } & \multicolumn{1}{c|}{ Business Activities } \\
\hline Buku 1 & $<\mathrm{Rp} \mathrm{1} \mathrm{trillion}$ & Basic business activities \\
\hline Buku 2 & Rp 1 trillion -5 trillion & Broader business activities and private equity \\
\hline Buku 3 & Rp 5 trillion - Rp 30 trillion & Broader business activities and private equity \\
\hline Buku 4 & $>\operatorname{Rp~30~trillion~}$ & Complex business activities and participation \\
\hline
\end{tabular}

(Source: Bank Indonesia, 2012)

Pursuant to Circular Letter of Bank Indonesia No. 6/23/DPNP/2011, assessment of the healthiness of banks in Indonesia can be classified based on the following criteria:

Table 2. Criteria for Bank Healthiness

\begin{tabular}{|c|c|c|c|c|c|c|c|}
\hline \multicolumn{6}{|c|}{ Criteria } & Rank & Category \\
\hline $\mathrm{ROA}>1,5 \%$ & $\mathrm{NIM}>3 \%$ & LDR $\leq 75 \%$ & BOPO $<94 \%$ & $\mathrm{CAR}>12 \%$ & $\mathrm{NPL}<2 \%$ & 1 & Very good \\
\hline $1,25 \%<\mathrm{ROA} \leq 1,5 \%$ & $2 \%<\mathrm{NIM} \leq 3 \%$ & $75 \%<\mathrm{LDR} \leq 85 \%$ & $94 \%<\mathrm{BOPO} \leq 95 \%$ & $9 \%<\mathrm{CAR} \leq 12 \%$ & $2 \%<\mathrm{NPL} \leq 5 \%$ & 2 & Good \\
\hline $0,5 \%<\mathrm{ROA} \leq 1,25 \%$ & $1,5 \%<\mathrm{NIM} \leq 2 \%$ & $85 \%<\mathrm{LDR} \leq 100 \%$ & $95 \%<\mathrm{BOPO} \leq 96 \%$ & $8 \%<\mathrm{CAR} \leq 9 \%$ & $5 \%<\mathrm{NPL} \leq 8 \%$ & 3 & Acceptable \\
\hline $0 \%<\mathrm{ROA} \leq 0,5 \%$ & $1 \%<\mathrm{NIM} \leq 1,5 \%$ & $100 \%<\mathrm{LDR} \leq 120 \%$ & $96 \%<\mathrm{BOPO} \leq 97 \%$ & $6 \%<\mathrm{CAR} \leq 8 \%$ & $8 \%<\mathrm{NPL} \leq 12 \%$ & 4 & Poor \\
\hline $\mathrm{ROA} \leq 0 \%$ & $\mathrm{NIM} \leq 1 \%$ & LDR $>120 \%$ & BOPO $>97 \%$ & $\mathrm{CAR} \leq 6 \%$ & NPL $>12 \%$ & 5 & Very poor \\
\hline
\end{tabular}

(Source: Bank Indonesia, 2011)

Based on a study by Sofyan (2003), banking performance can be measured using bank profitability. Wibowo (2013) states that Return on Assets (ROA) is used to measure bank profitability because Bank Indonesia as a bank supervisor and regulator prioritizes the value of bank profitability 
Studi Akuntansi \& Keuangan Indonesia

as measured by assets, which the funds come from the majority of public savings. Return on Assets (ROA) reflects a company's capability in generating profits through its operational activities. Moreover, Siamat (2002) argues that profitability ratio that is suitable for the banking sector is the Return on Assets (ROA).

According to previous empirical studies, there are many factors that contribute to the profitability of banks. These factors come from macroeconomic level and bank level. Recognizing different characteristics of commercial banks in Indonesia such as core capital size and business activities, understanding the determinant of the bank's performance within the bank-level data is valuable for identifying behavior of individual banks as well as for the micro-prudential objectives (Rachman, et al, 2018). There are previous empirical studies in Indonesia that scrutinize the banklevel determinants of the bank's profitability finding that net interest margin (NIM), loan to deposit ratio (LDR), operating expense to operating income ratio (BOPO), capital adequacy ratio (CAR) and non-performing loan (NPL) contribute to the profitability of the banks (e.g. Wibowo; 2013, and Widowati and Suryono, 2015).

In their study, Purwoko and Sudiyatno (2013) stated that the increase of interest income will spontaneously result in a decrease in the probability of a bank having a problematic situation. Therefore, an increase in a bank's NIM will cause an increase in bank profitability as indicated by an increase in ROA. The results of the study were in line with several studies conducted by Suryani et al. (2016), Ahmad (2015) and Suryani et al. (2016). However, research from Aini (2013) showed different results, where NIM had a insignificant negative effect on changes in earnings because banks tend to tighten lending and improve portfolio management. One study conducted by Marlina (2016) found that LDR of Buku 3 banks was the biggest among the other banks. This showed that Buku 3 banks' ability to repay depositors' withdrawals was better than the others. The results of the study were also supported by research conducted by Setiawan and Hermanto (2016). However, Ahmad (2015) showed slightly different results, where the LDR had a positive but not significant effect because banks were not in an optimal condition in providing loans and lending. In contrast to the previous results, the results of research in Greece conducted by Alexiou and Vogiazas (2009) found that LDR had a 
Studi Akuntansi \& Keuangan Indonesia

significant negative effect on bank profitability. The results of the study were in line with other studies by Bordeleau and Graham (2010) conducted in Canada and by Tan (2016) conducted in China.

Based on the results of study conducted by Aini (2013) and Sudiyatno and Suroso (2010), there is a negative relationship between BOPO and ROA. Because BOPO reflects the ability of a bank to maintain its operating efficiency, the lower BOPO had a fruitful impact on banks' profitability. Other studies conducted in other countries also showed the same results; one of them was by Athanasoglou et al. (2006) on banking in southeast Europe. The results of the study found that BOPO negatively affects bank profitability. The results of the study were in line with research conducted in Turkey by Akbas (2012) and in Greece by Alexiou and Vogiazas (2009). However, there was one study in China by Tan (2016) showing the opposite result, where overhead cost over total assets had a significant positive effect on earnings. He suggests that the more business activities run by banks, the higher cost was incurred so that the income might exceed the cost.

In a study conducted by Aini (2013), the high ratio of CAR showed large capital of a bank; thus, banks could excessively place funds from capital for a productive assets portfolio and that might impact interest income as well as earnings. This was also in line with the study conducted by Sudiyatno and Suroso (2010) as well as Athanasoglou et al. (2006) in southeast Europe. However, the results of study conducted by Widowati and Suryono (2015) showed the opposite. According to their research, CAR had a significant negative effect on ROA because the huge amount of capital possessed by banks was not managed effectively and was placed on investments that generate profits. Finally, this high CAR was not able to contribute to the level of profitability of banks. The results of the study were in line with the research conducted by Ahmad (2015), Akbas (2012), Alexiou and Vogiazas (2009) and Tan (2016).

According to Hindarto (2011), NPL significantly had a significant negative effect on ROA because with the increase in the amount of loans disbursed, the NPL also increased. As a result, this higher NPL caused ROA to decrease. This research was also supported by Purwoko and Sudiyatno (2013) findings that if a bank has high NPL, it might raise costs, both the cost of reserves for productive 
Studi Akuntansi \& Keuangan Indonesia

assets and other assets. This potentially caused losses to banks and the impact on bank performance would be increasingly decreased. However, according to Suryani et al. (2016), NPL had no effect on profitability. The reason was the low credit risk can be anticipated by banks that have large capital. Research conducted by Aini (2013) also concluded the same results. Other studies conducted in other countries showed the same results, one of which was research in Greece by Alexiou and Vogiazas (2009), which found that high NPL could be caused by less integrated risk management and policies that provided indecisive loans. The results of this study were supported by other studies carried out by Athanasoglou et al. (2006), Görevlisi (2012) and Tan (2016).

One study conducted by Athanasoglou et al. (2006) in southeast Europe showed that bank size had a significant positive effect on profitability. This was in accordance with the European Commission that concluded when the banking system reached a higher level in terms of technology and productivity, the opportunity to conduct economic activities was greater. This research was supported by Alexiou and Vogiazas (2009) where the logarithm of total assets (bank size) had a strong positive impact on profitability of the banks. On the other hand, research conducted by Tan (2016) in China showed that the logarithm of total assets (bank size) had a negative influence on bank profitability. That was because small banks were easier to regulate and bank managers could focus more on managing business activities, which had an impact on increasing profitability. This research was supported by Akbas (2012).

Based on previous empirical studies, scrutinizing bank-specific factors are important to understand the behavior of individual banks (Rachman, et. al, 2018). Moreover, based on the findings from studies by Wibowo (2013) and Widowati and Suryono (2015), there are five factors that affect bank's profitability, namely net interest margin (NIM), loan to deposit ratio (LDR), operating expense to operating income ratio (BOPO), capital adequacy ratio (CAR) and non-performing loan (NPL). Based on previous empirical studies in various countries, the hypotheses development is as follow.

\section{Hypotheses Development}

The Effect of Net Interest Margin (NIM) on Return on Asset (ROA) 
Studi Akuntansi \& Keuangan Indonesia

When bank deposits increase, banks can channel these funds in the form of credit that can create interest income. With the increase in net interest income, the NIM will also increase as well as profitability. This shows that if the bank is effective in placing its productive assets in the form of credit, thus having an impact on increasing net income (Purwoko and Sudiyatno, 2013). Thus, bank profitability described by ROA will increase.

$\mathrm{H}_{1} \mathrm{a}$ : NIM has a positive effect on the profitability of BUKU 4 Banks.

$\mathrm{H}_{1}$ b: NIM has a positive effect on the profitability of BUKU 3 Banks.

The Effect of Loan to Deposit Ratio (LDR) on Return on Asset (ROA)

The bank collects third party funds for being distributed in the form of credit. When the amount of credit increases, the LDR ratio will also increase. The more loans are given to the customers, the greater the interest income. This shows that banks are effective in managing third party funds to generate interest income (Marlina, 2016). Thus, net income will increase along with bank profitability. $\mathrm{H}_{2} \mathrm{a}$ : LDR has a positive effect on the profitability of BUKU 4 Banks.

$\mathrm{H}_{2} \mathrm{~b}$ : LDR has a positive effect on the profitability of BUKU 3 Banks.

The Effect of Operating Expense to Operating Income (BOPO) on Return on Asset (ROA)

Banks in BUKU 3 and BUKU 4 categories tend to have large operational costs due to its wide span of business activities. If these large operational costs are not accompanied by an increase in bank operating income, the BOPO ratio will increase. This illustrates that the bank is inefficient in managing its operating expenses thus it has an impact on decreasing net income and decreasing profitability (Aini, 2013; Sudiyatno and Suroso, 2010).

$\mathrm{H}_{3} \mathrm{a}$ : BOPO has a negative effect on the profitability of BUKU 4 Banks.

$\mathrm{H}_{3}$ b: BOPO has a negative effect on the profitability of BUKU 3 Banks.

The Effect of Capital Adequacy Ratio (CAR) on Return on Asset (ROA) 
Studi Akuntansi \& Keuangan Indonesia

With the large bank capital owned by a bank, it is able to fund risk-weighted assets to prevent a decrease in profitability. In addition, also with large bank capital, banks have the opportunity to expand credit to generate profits by placing these funds in productive asset portfolios. Thus, interest income and net income will increase along with the larger capital, which will also have an impact on increasing bank profitability (Aini, 2013; Athanasoglou et al., 2006; Sudiyatno and Suroso, 2010).

$\mathrm{H}_{4} \mathrm{a}$ : CAR has a positive effect on the profitability of BUKU 4 Banks.

$\mathrm{H}_{4} \mathrm{~b}$ : CAR has a positive effect on the profitability of BUKU 3 Banks.

The Effect of Non-Performing Loan (NPL) on Return on Asset (ROA)

When banks use third party funds to be channeled into credit, more customers will borrow money. If lending is not done carefully, there will be a chance for problematic credit, where there is a possibility for customers who are unable to repay the loan principal and interest. The more customers who fail to pay, the higher the NPL ratio. With the increase in NPL ratio, net income will decrease and affect bank profitability (Hindarto, 2011; Purwoko and Sudiyatno, 2013)

$\mathrm{H}_{5} \mathrm{a}$ : NPL has a negative effect on the profitability of BUKU 4 Banks.

$\mathrm{H}_{5}$ b: NPL has a negative effect on the profitability of BUKU 3 Banks.

The Effect of Buku Categories (Buku) on Return on Asset (ROA)

If seen from the ROA trend over the past 4 years, there was a positive correlation between the Buku category and profitability generated by banks. The amount of core capital will affect the Buku category. The higher the Buku category, the more permissible business activities, where these activities will affect a bank's income. Thus, if the bank has a lot of business activities that can be done, the profitability shown through ROA will also increase. This hypothesis is built based on the proof that bank size had a significant positive effect on profitability (Athanasoglou et al., 2006).

$\mathrm{H}_{6}$ : Core capital-based (Buku) category and bank profitability have a positive relationship.

\section{Research Framework}


Studi Akuntansi \& Keuangan Indonesia

Base on literature review and hypotheses development above, we construct the research framework below:



Figure 3. Research Framework

\section{Method}

\section{Population and Sample}

The population in this research is all banks in Indonesia with a total number of 116 banks. The technique in determining the sample was purposive sampling, namely commercial banks categorized as Buku 3 and Buku 4 class according to the 2018 list of banks by core capital or "Buku" category. There were 24 banks from Buku 3 class and 3 banks from Buku 4 class with a total of 27 banks as the sample. The data was derived from financial statements of banks downloaded from the website of each bank and the Bloomberg terminal over the period of 2009 - 2018 resulting in 270 observations. The type of data used in this study is panel data which is a combination of time series and cross section.

\section{Variables}

There was one dependent variable, Return on Assets (ROA), and five independent variables applied in this study. ROA is a financial ratio that can assess a company's ability to create profits at the level of income and assets. Based on Bank Indonesia Circular Letter (SE) No. 3/30 / DPNP dated 14 December 2001, this ratio is calculated as follows: 
Studi Akuntansi \& Keuangan Indonesia

ROA $=\frac{\text { Net Income }}{\text { Total Asset }} \times 100 \%$

Net Interest Margin is the ratio of the interest income produced by the bank and the value of the interest paid to the creditor against the total productive interest on the asset. Based on Bank Indonesia Circular Letter (SE) Number 3/30 / DPNP dated 14 December, 2001, the NIM ratio can be computed as follows.

$N I M=\frac{\text { Net Interest Income }}{\text { Average Productive Asset }} \times 100 \%$

Loan to Deposit Ratio is a liquidity ratio used to see the effectiveness and efficiency of banks in managing funds to be distributed in the form of credit to produce banks' profitability. Based on Bank Indonesia Circular Letter (SE) No. 3/30 / DPNP dated 14 December, 2001, LDR can be formulated as follows:

$L D R=\frac{\text { Total Credit }}{\text { Total Deposit }} \times 100 \%$

Operational Expenses to Operating Income is a ratio that can assess the level of efficiency of bank management in controlling costs incurred for daily operations with income derived from operations. Based on Bank Indonesia Circular Letter (SE) No. 3/30 / DPNP dated 14 December 2001, BOPO is formulated as follows:

$B O P O=\frac{\text { Operating Cost }}{\text { Operating Income }} \times 100 \%$

Capital Adequacy Ratio is able to show the ability of banks to supply funds to be allocated to conquer the possibility of loss risk. Based on Bank Indonesia Circular Letter (SE) No. 3/30 / DPNP dated 14 December, 2001, CAR can be formulated as follows:

$C A R=\frac{\text { Core Capital }}{\text { Risk }- \text { weighted Asset }} \times 100 \%$ 
Studi Akuntansi \& Keuangan Indonesia

Non-Performing Loans is a ratio that is able to assess the quality of productive assets. Based on Bank Indonesia Circular Letter (SE) No. 3/30 / DPNP dated 14 December, 2001, NPL is formulated as follows:

$$
N P L=\frac{\text { Non }- \text { performing loan }}{\text { Total credit }} \times 100 \%
$$

The equation model for this study is as follows:

$$
R O A_{i t}=\propto+N I M_{i t} \beta_{1}+L D R_{i t} \beta_{2}+B O P O_{i t} \beta_{3}+C A R_{i t} \beta_{4}+N P L_{i t} \beta_{5}+u_{i t}
$$

\section{Buku category}

In this study, the sample banks are grouped into 2 classes namely Buku 4 and Buku 3 category. Banks that have core capital of more than Rp 30 trillion are classified as the member of Buku 4 category while banks that have core capital of Rp 5-30 trillion are classified as the member of Buku 3 category. To analyze the effect of the group classification on the dependent variable, dummy variables are applied where "1" indicates banks in Buku 4 and "0" indicates banks in Buku 3.

\section{Data Analysis}

The method used to analyze the effect of dependent variables to independent variables is fixed effect regression for Buku 4 only as well as Buku 4 and Buku 3, and random effect regression for Buku 3. Regressions were carried out separately three times, namely for the sample of Buku 4 banks only, Buku 3 banks only, and the combination of Buku 4 and Buku 3 banks. However, before regressions were applied, the model was estimated using the Chow test, Hausman test, and Lagrange Multiplier test. Having estimated the model, a classic assumption test was undertaken to make sure that the regressions resulted in the Best Linear Unbiased Estimator (BLUE) (Gujarati, 2012). This study applies a significance level of 5 percent in conducting the t-test and F-test. For heteroskedasticity problems, Wald Test and Robust Test were applied to eliminate heteroscedasticity in all estimation models by increasing the range of the standard error.

\section{Results and Discussion}

\section{Descriptive statistics}


Table 3. Descriptive Statistics (in percent)

\begin{tabular}{|c|c|c|c|c|c|c|c|c|c|c|c|c|}
\hline \multirow[b]{2}{*}{ Variable } & \multicolumn{4}{|c|}{ BUKU $4(n=4)$} & \multicolumn{4}{|c|}{ BUKU $3(n=23)$} & \multicolumn{4}{|c|}{ COMBINED BUKU 4 dan BUKU $3(n=27)$} \\
\hline & Mean & Std.Dev & Min & Max & Mean & Std.Dev & Min & Max & Mean & Std.Dev & Min & Max \\
\hline ROA & 3.501 & 0.768 & 1.7 & 5.15 & 1.957 & 1.075 & -4.9 & 5.57 & 2.193 & 1.173 & -4.9 & 5.57 \\
\hline NIM & 6.590 & 1.361 & 5.04 & 10.77 & 5.503 & 2.329 & 1.37 & 14 & 5.669 & 2.241 & 1.37 & 14 \\
\hline LDR & 78.684 & 10.248 & 50.3 & 95.46 & 98.630 & 35.808 & 45.6 & 256.35 & 95.585 & 33.957 & 45.6 & 265.35 \\
\hline BOPO & 68.522 & 5.976 & 58.2 & 84.9 & 80.839 & 12.030 & 44.76 & 150.8 & 78.929 & 12.147 & 44.76 & 150.8 \\
\hline CAR & 17.618 & 3.133 & 12.7 & 23.4 & 18.794 & 5.452 & 8.34 & 50.48 & 18.614 & 5.179 & 8.34 & 50.48 \\
\hline NPL & 2.129 & 1.064 & 0.4 & 4.7 & 2.390 & 1.544 & 0.08 & 8.8 & 2.350 & 1.482 & 0.08 & 8.8 \\
\hline
\end{tabular}

Overall, there are 4 banks in the Buku 4 class and 23 banks in Buku 3 class over 2009-2018 resulting in 40 observations in the Buku 4 model, 230 observations in the Buku 3 model and 270 observations in the combined model. As can be seen in Table 3, ROA of the sample banks averagely stands at $3.5 \%$ for the Buku 4 class, $1.96 \%$ for the Buku 3 class, and $2.19 \%$ for the combined classes. Moreover, the standard deviation of the ROA in the Buku 4 class is $0,77 \%$ while in the Buku 3 and in the combined model the standard deviation is around $1.1 \%$. This shows that the banks in the Buku 4 model are on average more profitable than banks in other categories with relatively less dispersion compared to the other categories.

In terms of NIM, banks in the Buku 4 class have an average NIM of $6.6 \%$ while banks in the Buku 3 and the combined classes have lower NIM of 5.5\% and 5.67\% respectively. In addition, standard deviation of the NIM in the Buku 4 class is $1.36 \%$ where in the Buku 3 category and the combination of Buku 4 and Buku 3 category have $2.3 \%$ and $2.2 \%$ respectively. It means that banks in the Buku 4 class relatively have higher but less dispersed NIM. When we look at the LDR, we can see that banks in the Buku 4 class have a lower LDR of $78.7 \%$ than other classes where the LDR is $98.6 \%$ in the Buku 3 category and $95.6 \%$ in the combination of Buku 4 and Buku 3 category. However, when the standard deviations of the LDR are observed, banks in the Buku 4 have a narrow distribution compared to banks in other categories.

In addition, the average BOPO ratio of banks in the Buku 4, Buku 3 and combination of Buku 4 and Buku 3 is $68.5 \%, 80.8 \%$ and $78.9 \%$ respectively while the standard deviation is $5.9 \%, 12 \%$ and 12.1 for the three categories. When CAR is observed, banks in the Buku 4 category have the lowest average value of $17.6 \%$ while the banks in the Buku 3 and in the combined category have around 


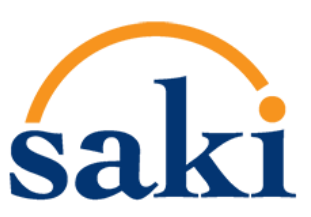

Studi Akuntansi dan Keuangan Indonesia, Vol. 3, No. 1, 2020 |E-ISSN: 2654-6221

Studi Akuntansi \& Keuangan Indonesia

$18.6 \%$. Similarly, the banks in the Buku 4 category also have the lowest NPL ratio of $2.1 \%$ while the banks in the Buku 3 class and in the combined category have NPL ratio of $2.3 \%$. In terms of dispersion of the CAR, banks in the Buku 4 class have the lowest standard deviation of 3.1\% compared to 5.4\% and $5.1 \%$ in the Buku 3 category and in the combined category. Similarly, banks in the Buku 4 class also have the lowest standard deviation of $1 \%$ compared to the other category.

Based on the healthiness criteria for bank set forth in Circular Letter of Bank Indonesia No. 6/23/DPNP/2011, it can be summarized that in the category of Buku 4 banks, the ROA, NIM, BOPO and CAR ratios were classified as very good, while the LDR and NPL ratios were classified as good. For Buku 3 banks, it can be concluded that the ROA, NIM, BOPO and CAR ratios were classified as very good, the LDR ratio was classified as acceptable and NPL was classified as good. For the combined category of 4 Buku 4 and 23 Buku 3 banks, it can be concluded that the ROA, NIM, BOPO and CAR ratios were classified as very good, the LDR ratio was classified as acceptable and NPL was classified as good.

\section{Hypotheses Testing}

For the Buku 3 category, a random effect panel regression model is applied while for the Buku 4 category as well as the combination of Buku 3 and Buku 4 category, a fixed effect panel regression model is used. The summary of the regression results for the three models is presented in Table 4.

Table 4. Regression Results

\begin{tabular}{|c|c|c|c|c|c|c|c|c|c|c|c|c|}
\hline \multirow[b]{2}{*}{ Variable } & \multicolumn{4}{|c|}{ ROA BUKU $4(n=4)$} & \multicolumn{4}{|c|}{ ROA BUKU 3 (n=23) } & \multicolumn{4}{|c|}{ ROA COMBINED $(n=27)$} \\
\hline & Coef & $\begin{array}{l}\text { Std. } \\
\text { Error }\end{array}$ & $t$ & $P>|t|$ & Coef & $\begin{array}{c}\text { Robust } \\
\text { Std. Error }\end{array}$ & $z$ & $P>|z|$ & Coef & $\begin{array}{c}\begin{array}{c}\text { Robust } \\
\text { Std. Error }\end{array} \\
\end{array}$ & $t$ & $P>|t|$ \\
\hline (Constant) & 9.5095 & 0.5160 & 18.43 & $0.000^{* \cdots+\cdots}$ & 5.7868 & 1.6766 & 3.47 & $0.001^{* *}$ & 6.0351 & 1.6709 & 3.61 & $0.001^{* *}$ \\
\hline NIM & 0.3271 & 0.0406 & 8.04 & $0.000^{* \cdots}$ & 0.1900 & 0.0572 & 3.53 & $0.000^{* \cdots}$ & 0.2043 & 0.0627 & 3.26 & $0.003 * *$ \\
\hline LDR & -0.0103 & 0.0037 & -2.75 & $0.01^{*}$ & 0.0030 & 0.0043 & 0.13 & 0.895 & 0.0017 & 0.0065 & 0.27 & 0.791 \\
\hline BOPO & -0.0982 & 0.0064 & -15.2 & $0.000^{* * *}$ & -0.0601 & 0.0151 & -3.18 & $0.000^{* * *}$ & -0.6052 & 0.1510 & -4.01 & $0.000 * \cdots *$ \\
\hline CAR & -0.0237 & 0.0107 & -2.22 & $0.034^{*}$ & 0.0057 & 0.0126 & 0.15 & 0.880 & 0.0003 & 0.1105 & 0.03 & 0.979 \\
\hline NPL & -0.0972 & 0.0451 & -2.16 & $0.039^{*}$ & -0.1742 & 0.0599 & -2.70 & $0.007^{* *}$ & -0.1702 & 0.0649 & -2.62 & $0.014^{*}$ \\
\hline BUKU & - & - & - & $\therefore$ & - & - & - & $=$ & 0.0675 & 0.1781 & 0.38 & 0.708 \\
\hline$R^{2}$ & \multicolumn{4}{|c|}{0.8886} & \multicolumn{4}{|c|}{0.7178} & \multicolumn{4}{|c|}{0.7562} \\
\hline Adj $R^{2}$ & \multicolumn{4}{|c|}{0.8734} & \multicolumn{4}{|c|}{0.7232} & \multicolumn{4}{|c|}{0.7481} \\
\hline F-stat & \multicolumn{4}{|c|}{95.32} & \multicolumn{4}{|c|}{138.94 (Wald Chi ${ }^{2}$ Statistic) } & \multicolumn{4}{|c|}{99.89} \\
\hline F Sig & \multicolumn{4}{|c|}{0.000} & \multicolumn{4}{|c|}{0.000} & \multicolumn{4}{|c|}{0.000} \\
\hline
\end{tabular}


Studi Akuntansi \& Keuangan Indonesia

Notes:* significant at 10 percent confidence level; ** significant at 5 percent confidence level; *** significant at 1 percent confidence level

For the Buku 4 model, NIM, LDR, BOPO, CAR, and NPL are proven to significantly affect ROA. Furthermore, NIM is found to have a negative relationship with ROA while LDR, BOPO, CAR, and NPL have a positive relationship with ROA. Moreover, from the result of the Buku 4 model we can see that the constant value is 9.509 , meaning that when all independent variables have the value of 0 , the ROA is 9.509 . NIM has a coefficient of +0.3271 means that when it increases by one percent, ROA will increase by 0.3271 or 32.71 per cent. The coefficient of the LDR variable of -0.0103 indicates that when LDR increases by one per cent, ROA will decrease by 0.0103 or 1.03 per cent. The coefficient of the BOPO variable of -0.0982 means that when it increases by one per cent, ROA will decrease by 0.0982 or 9.82 per cent. The coefficient of the CAR variable of -0.0237 indicates that when CAR increases by one per cent, the value of profitability (ROA) will decrease by 0.0237 or 2.37 per cent. The coefficient on the NPL variable of -0.0972 indicates that when NPL increases by one per cent, the profitability value (ROA) will decrease by 9.72 per cent. Among other independent variables, BOPO has the highest contribution to ROA.

On the other hand, for the Buku 3 model, only NIM, BOPO, and NPL are significant to affect ROA. Furthermore, similar to the Buku 4 model, NIM is found to have a negative relationship with ROA while BOPO and NPL have a positive relationship with ROA. The constant value is 5,787, meaning that when all independent variables have the value of 0 , the ROA value is 5.7868 . The coefficient of NIM of +0.1900 indicates that when the NIM increases by one per cent, the profitability value (ROA) will increase by 0.1900 or 19 per cent. The coefficient on the BOPO variable of -0.0601 indicates that when BOPO increases by one per cent, ROA will decrease by 0.0601 or 6.01 per cent. The coefficient of NPL of -0.1742 indicates that when NPL increases by one per cent, the ROA will decrease by 0.1742 or 17.42 percent. Among other independent variables, NIM has the highest contribution to ROA. 
Studi Akuntansi \& Keuangan Indonesia

For the combination of Buku 4 and Buku 3 model, the results show consistency with the Buku 3 model where NIM has a significant positive relationship with ROA but BOPO and NPL have a negative relationship with ROA. Since the sample for Buku 3 is larger than Buku 4, the results of the combined model show consistency with Buku 3 only model. The constant value in the regression is 6.03513 , meaning that when all the independent variables have the value of 0 , the ROA value is 6.03513. The coefficient of NIM of +0.2043 indicates that when it increases by one percent, ROA will increase by 0.2043 or 20.43 per cent. The coefficient of BOPO of -0.6052 indicates that when it increases by one per cent, ROA will decrease by 0.0605 or 6.05 percent. The coefficient of NPL of 0.1701 indicates that when it increases by one per cent, ROA will decrease 17.01 per cent. Among all independent variables, BOPO has the highest contribution that affects ROA.

In addition, all the three models are found significant in terms of the F-test indicating that independent variables are able to affect the variance in the ROA. Furthermore, among the three models, Buku 4 model is the best model proven by the highest adj- $\mathrm{R}^{2}$ of 87.34 per cent where Buku 3 model has adj- $\mathrm{R}^{2}$ of 72.32 per cent and the combined model has adj- $\mathrm{R}^{2}$ of 74.81 per cent.

\section{Discussion}

The Effect of Net Interest Margin (NIM) on Return on Asset (ROA)

The regression results of the three models show that there is a significant positive relationship between NIM and ROA. The reason is that an increase in the third-party deposits disbursed in the form of loans will generate loan interest income that will increase the value of the NIM, which reflects that the bank is effective in placing its productive assets in the form of credit. This will have an impact on an increasing net income. The results of this study were in line with studies conducted by Purwoko and Sudiyatno (2013), Suryani et al. (2016), Ahmad (2015) and Suryani, et al (2016).

\section{The Effect of Loan to Deposit Ratio (LDR) on Return on Asset (ROA)}

LDR and CAR are only found significant in the Buku 4 model. This is because not all thirdparty deposits of Buku 4 banks were channeled in the form of credit, meaning Buku 4 banks were more selective in providing loans. This had an impact on small non-performing loans; thus, optimal 
Studi Akuntansi \& Keuangan Indonesia

interest income will increase net income. This was consistent with previous research by Alexiou and Vogiazas (2009), Bordeleau and Graham (2010) and Tan (2016).

The Effect of Operating Expense to Operating Income (BOPO) on Return on Asset (ROA)

It is also found that BOPO has a significant negative effect on profitability (ROA). This result was in accordance with the initial hypotheses. Increased operating expenses that are not followed by an increase in operating income showed that banks were less effective and efficient in managing operational costs to be used as operating income. Thus, the BOPO will increase, meaning net income will decrease followed by a decrease in profitability. The results of this study were also in line with previous studies of Aini (2013), Sudiyatno and Suroso (2010), Suryani et al (2016), Athanasoglou et al. (2006), Görevlisi (2012) and Alexiou and Vogiazas (2009).

\section{The Effect of Capital Adequacy Ratio (CAR) on Return on Asset (ROA)}

The reason why CAR had a significant negative effect on ROA is that banks in Buku 4 category have a large amount of capital which will make more idle cash increase so that there are additional costs in managing the idle cash. These results were consistent with the results of research conducted by Widowati and Suryono (2015). When large amounts of capital that banks were not effectively managed and not allocated to investments that generated profits (for example, development of feebased income), the contribution to increase profitability was not achieved. The results of this study were supported by the results of other studies conducted by Ahmad (2015), Akbas (2012), Alexiou and Vogiazas (2009) and Tan (2016).

The Effect of Non-Performing Loan (NPL) on Return on Asset (ROA)

The results show that there is a significant negative relationship between NPL and ROA. This indicates that if a bank is not careful in providing credit, it will increase the chance of problematic loans so that resulting in an increase in the NPL. This will have an impact on lowering net income that will ultimately reduce bank profitability. The results of this study were in accordance with previous research Hindarto (2011), Purwoko and Sudiyatno (2013), Alexiou and Vogiazas (2009), Athanasoglou et al. (2006), Akbas (2012), and Tan (2016). 
Studi Akuntansi \& Keuangan Indonesia

The Effect of Buku Categories (Buku) on Return on Asset (ROA)

From the regression results, it is shown that the relationship between buku category and profitability is not significant indicating that the bank classification has no effect on bank profitability. Moreover, it means that banks in the Buku 4 category with larger core capital and more complex business activities are not proven to have different profitability level than those banks in the Buku 3 category with lower core capital size and more limited business activities.

\section{Conclusion, Implication, Limitation and Recommendation}

This study aims at scrutinizing bank-specific factors that contribute to the profitability of Indonesian banks having core capital size of above Rp 5 trillion that is classified as banks in Buku 3 category (core capital within Rp 5 - 30 trillion) and Buku 4 category (core capital > Rp 30 trillion). By applying a panel regression model, it is concluded that NIM, BOPO and NPL significantly affect the profitability of Indonesian banks. NIM is found to have a negative effect on profitability while BOPO and NPL affect profitability in a positive way. However, LDR and CAR are only found significant to affect profitability of banks having more than Rp 30 trillion core capital (banks in Buku 4 class). These results demonstrate that profitability of banks that have the highest core capital are affected by more factors than banks with lower core capital meaning that largest banks should pay attention to more factors to oversee its profitability. In addition, core capital categorization is proven to have no effect on bank profitability meaning that banks with larger core capital and more complex business activities are not necessarily more profitable than those banks with lower capital.

By understanding these bank-specific factors that contribute to the variability of bank profitability, management of banks as well as banking sector authority might be able to oversee that particular financial ratios to oversee the bank's individual profitability. Moreover, management of the largest banks should improve its effectiveness in capital management and allocation of funds invested to generate higher profits. One example is improving fee-based or non-interest income that can be derived from various business activities. The higher core capital should be used with more optimal, effective and efficient operations of the bank itself. Without the effort given by a bank, it will not 
Studi Akuntansi \& Keuangan Indonesia

increase bank profitability. The results of this study also support the reasons banks do not always set targets to become a bank in the Buku 4 category.

In terms of limitation, this research applies to a considerably limited number of samples especially on the banks in Buku 4 category. The reason is that in the Indonesian banking sector, there are only a few banks that have a core capital size of more than Rp 30 trillion. Furthermore, bank profitability might be affected by other factors that are not under the banks' control such as macroeconomic factors. However, these factors are not analyzed in our study.

Considering the limitation of this study, it is suggested that future studies can increase the number of observations and also consider macroeconomic indicators, such as inflation rate, interest rate, gross domestic product, and many others. It would aim to provide a broad picture of the determinants of bank profitability, both microeconomic and macroeconomic variables. In addition, because the Buku 4 bank sample is too small in Indonesia, it was suggested to use a fairly long horizon to obtain accurate results. Moreover, further research can apply the core capital in amount instead of classification to find variability in bank profitability. Lastly, it is also suggested that future study might investigate the source of revenue between non-interest revenue and interest revenue for the banking industry to provide more interesting insight. This research topic can be explored deeper in the next few years, given the banking conditions in Indonesia that are still in a developing state and have the potential to be more advanced going forward.

\section{References}

Ahmad, G. N. (2015). Determinants of Bank Profitability: Case Study on Local Development Bank. Jurnal Keuangan dan Perbankan, 19(3), 431-438.

Aini, N. (2013). The Impact of CAR, NIM, LDR, NPL, BOPO, and Productive Asset Quality on the Change in Income. Dinamika Akuntansi, Keuangan, dan Perbankan, 2(1), 14-25.

Akbas, H. E. (2012). Determinants of Bank Profitability: An Investigation on Turkish Banking Sector. Öneri Dergisi, 10(37), 103-110.

Athanasoglou, P. P., Delis, M. D., Staikouras, C. K., (2006). Determinants of Bank Profitability in the South Eastern European Region, Bank of Greece, Munich Personal RePEc Archive Working Paper, 10274.

Alexiou, C., Vogiazas, S. (2009). Determinants of Bank Profitability: Evidence from the Greek Banking Sector. Ekonomski anali, 54(182), 93-118. 
Studi Akuntansi \& Keuangan Indonesia

Bank Indonesia. (2012). Bank Indonesia Regulation No. 14/26/PBI/2012 dated 27 December 2012 on Business Activities and Office Networks Based on Bank Core Capital. Accessed on 28 October 2019 through https://www.bi.go.id/id/peraturan/perbankan/pages/pbi_142612.aspx

Bordeleau, É., Graham, C. (2010). The Impact of Liquidity on Bank Profitability. Bank of Canada Working Paper, p.38. Financial Stability Department, Bank of Canada.

Christiano, M., Tommy, P., Saerang, I. (2014). The Analysis of Financial Ratio to Measure Private Banks Profitability on the Indonesian Stock Echange. Jurnal EMBA, 2(4), 817-830.

Gujarati, D.N. (2012) Basic Econometrics. Basic Econometrics ( $5^{\text {th }}$ ed.). Noida: Tata McGraw-Hill Education.

Görevlisi, Ö. (2012). Determinants of Bank Profitability: An Investigation on Turkish Banking Sector. Öneri.C.10.S.37 Ocak, 103-110.

Harahap, S. S. (2002). Critical Analysis on Financial Statement. Jakarta: PT Raja Grafindo Persada.

Hindarto, C. (2011). The Analysis of the Impact of CAR, NIM, LDR, NPL, BOPO, and KAP on Return on Asset. Jurnal Bisnis Strategi, 20(2), 15-40.

Marlina, R. (2016). Analysis of Financial Performance Differences Bank In Indonesia Based on Buku. Academy of Strategic Management Journal, 15(3), 176-187.

Otoritas Jasa Keuangan. (2018). Indonesian Banking Statistics. Accessed on 20 October 2018 through https://www.ojk.go.id/id/kanal/perbankan/data-dan-statistik/statistik-perbankanindonesia/default.aspx

Otoritas Jasa Keuangan. (2016). POJK Nomor 6/POJK.03/2016. Accessed on 20 October 2018 through https://www.ojk.go.id/id/kanal/perbankan/regulasi/peraturan-ojk/Pages/pojkkegiatan-usaha-dan-jaringan-kantor-berdasarkan-modal-inti-bank.aspx

Purwoko, D., Sudiyatno, B. (2013). Factors Affecting Bank Performance. Jurnal Bisnis dan Ekonomi, 20(1), 25-39.

Rachman R A, Kadarusman Y B, Anggriono K, et al. 2018. Bank-specific Factors Affecting Nonperforming Loans in Developing Countries: Case Study of Indonesia. The Journal of Asian Finance, Economics and Business, 5(2), 35-42

Setiawan, A., Hermanto B. (2016). Comparative Study: Determinant on Banking Profitability between Buku 4 and Buku 3 Bank in Indonesia. BENEFIT Jurnal Manajemen dan Bisnis, 2(1), 92 101.

Sudiyatno, B., Suroso, J. (2010). The Analysis of the Impact of DPK, BOPO, CAR, and LDR on Financial Performance of Banking Sector on Indonesian Stock Exchange. Dinamika Keuangan dan Perbankan, 2(2), 125-137.

Suryani, A., Suhadak., Hidayat, R. (2016). The Impact of Capital Adequacy Ratio, Operating Expense on Operating Income Ratio, Loan to Deposit Ratio, Net Interest Margin, and Non Performing Loan on Return on Asset. Jurnal Administrasi Bisnis, 33(1), 105-113.

Sutrisno. (2012). Theory, Concept, and Application of Financial Management. Yogyakarta: EKONISIA.

Tan, Y. (2016). The Impact of Risk and Competition on Bank Profitability in China. Journal of International Financial Markets, Institutions and Money, 40, 85-110

Wibowo, E.S. (2013). The Analysis of Interest Rate, Inflation, CAR, BOPO, NPF on Sharia Bank Profitability. Diponegoro Journal of Management, 2(2), 1-10.

Widowati, S. A., Suryono, B. (2015). The Effect of Financial Ratio on Profitability in the Indonesian Banking Sector. Jurnal Ilmu \& Riset Akuntansi, 4(6), 1-15. 